\title{
Increasing Production and Quality of Chrysanthemum Cut Flowers Through the Application Biological Agents
}

\author{
Anak Agung Sagung Putri Risa Andriani ${ }^{*}$, I Gusti Made Arjana², Sang Ayu Made \\ Putri Suryani $^{3}$ \\ Faculty of Agriculture, Universitas Warmadewa, Denpasar, Bali-Indonesia \\ \{putri.ris69@yahool.com $\left.{ }^{1}\right\}$
}

\begin{abstract}
This research is entitled to increase the production and quality of chrysanthemum cut flowers through the application of biological agents, with the aim of knowing the dosage of Trichoderma sp. and the concentration of Beauveria bassiana and its interaction on chrysanthemum cut flowers. The research method used factorial randomized block design in the field in a green house. This study uses two factors, namely: the first factor, the dose of Trichoderma sp consists of 3 levels each: 0.25 tonnes ha.- $1,0.50$ ton ha-1, and 0.75 ton ha-1. The second factor of Beauveria bassiana consists of 3 levels, namely: $15 \mathrm{~g} / 1,30 \mathrm{~g} / 1$, and $45 \mathrm{~g} / \mathrm{l}$. The results showed the interaction between the doses of Trichoderma sp. and the concentration of Beauveria bassiana had no significant effect on all observed variables. Treatment of Trichoderma sp. very significant effect $(\mathrm{P}<0.01)$ on all observed variables. The highest economic weight of fresh flowers and the lowest intensity of pest attack occurred in the treatment dose of Trichoderma sp 1.0 ton ha- 1 that isamounting to $85.97 \mathrm{~g}$ and $25.19 \%$ when compared to the lowest treatment. The treatment of Beauveria bassiana concentration had a significant effect $(\mathrm{P}<0.05)$ on all observed variables, had a very significant effect $(\mathrm{P}<0.01)$ on the maximum plant height and flower stalk height. Treatment concentration of Beauveria bassiana $45 \mathrm{~g} / 1$ produce the highest economic weight of fresh flowers and the lowest intensity of disease attack of $79.55 \mathrm{~g}$ and $42.08 \%$ when compared to the lowest treatment.
\end{abstract}

Keywords: Trichoderma Sp; Beauveria Bassiana; Chrysanthemum Cut Flowers.

\section{Introduction}

Chrysanthemum (Dendranthema grandiflora, Tzvelev) or known as chrysanthemum flower, is a commodity that has a high economic value so that it has the potential to be developed commercially as a basic component in agribusiness, both as cut flowers, potted ornamental plants, and medicinal plants [1]. Chrysanthemum is one of the leading floricultural products developed in several centers, especially to meet the domestic market. The use of chrysanthemum in each flower arrangement is very dominant, reaching $30-65 \%$. This is quite prospective to continue to develop both the quality, quantity and development of the chrysanthemum business industry. Chrysanthemum cultivation business which was originally concentrated in Java, has now spread widely to Bali. 
Chrysanthemum flower production in Java and Bali has not been able to meet market demand because productivity is still low. Increased production needs to be continuously increased through both extensification and intensification. Chrysanthemum planting in Bali is currently only concentrated in Buleleng and Tabanan districts, so it needs to be developed in other potential areas [2]. Not all areas that have the potential have been planted with ornamental plants, due to various considerations such as being far from the marketing center, lack of adequate infrastructure, limited knowledge of cultivation, harvesting and post-harvest handling. Increasing production through intensification often encountered problems including pest and disease attacks, planting spacing, controlling soil moisture with mulch, determining the optimum dosage of organic and inorganic fertilizers, post-harvest (sorting, grading and packaging) and management of the production system. These cultivation factors are the cause of low production and quality of chrysanthemum flowers which affect the selling price of chrysanthemums as cut flowers [3].

Pests and diseases can cause a significant decrease in the quality and quantity of chrysanthemum production. The use of biological agents is a solution to controlling pests and diseases without damaging the surrounding environment.

The formulation of the problem faced by farmers is the attack of pests and diseases, especially leaf rust, which is related to the low production and quality of chrysanthemum cut flowers, due to the continuous use of inorganic materials which causes immunity to disturbing organisms. The use of biological agents that are antagonistic is expected to be able to control pests and diseases in chrysanthemum cut flowers.

Based on the foregoing, it is necessary to carry out research to increase the production and quality of chrysanthemum flowers through the application of biological agents which will later be used by farmers to support the production and quality of chrysanthemums which at the same time will increase farmers' income.

\section{Methods}

\section{Location, Time and Research Material}

Research located in Pancasari Village, Sukasada District, Buleleng Regency, which is 60 $\mathrm{km}$ away with an altitude of 1,247 meters above sea level and an average temperature of $17^{\circ}$ $\mathrm{C}$ to $20^{\circ} \mathrm{C}$, the research location can be seen in Figure 1. When the study began in the month May-November 2020. The research materials used included: chrysanthemum cuttings (standard type Fiji variety), biological agents, organic and inorganic fertilizers, fungicides, insecticides, and acaricides.

\section{Research Methods}

The research method used factorial randomized block design in the field in a plastic house. This study uses two factors, namely: the first factor, the dose of Trichoderma sp consists of 3 levels each: 0.25 tonnes ha.- $1,0.50$ ton ha- 1 , and 0.75 ton ha- 1 . The second factor of Beauveria bassiana consists of 3 levels, namely: $15 \mathrm{~g} / 1,30 \mathrm{~g} / 1$, and $45 \mathrm{~g} / 1$. The treatment was repeated 3 times, so that 27 experimental units were needed.

The trial implementation includes: media preparation,Clean, cultivate and level land for cut chrysanthemum cultivation and provide a suitable root system for cut flower production, regulate soil aeration to maintain air exchange in the soil and comply with standard tillage 
procedures. Before the land is cultivated, the land is cleared of crop residues, the land is hoeed to a depth of $30 \mathrm{~cm}$, then leveling is carried out.

Making the beds, after the soil is processed then the beds are $1 \mathrm{mx} 1 \mathrm{~m}$ in size, the distance between the beds is $30 \mathrm{~cm}$, while the distance between replicates is $50 \mathrm{~cm}$. Furthermore, fertilization and basic fertilizers were carried out and Trichoderma sp treatment based on different doses. Beauveria bassiana was given 3 times at the age of 21 days, 42 days and 63 after planting. The plan of the research place can be seen in Figure 2.

Fertilization, carried out before planting, namely organic and inorganic fertilizers as basic fertilizers with the fertilizer dosage given as recommended.

Planting is done in the afternoon with a spacing of $12.5 \mathrm{~cm} \times 12.5 \mathrm{~cm}$, with one chrysanthemum cuttings per hole. Plant maintenance, watering is carried out with drip irrigation according to the conditions in the field, embroidery is done after the plants are a week old after planting, weeding is adjusted to the growth of pests that grow in the field, pest and disease control is adjusted to the type of plant disturbing organisms with pesticide concentrations in accordance with its function to control these plant pests. Po observe the growth and development of plants until harvest.

\section{Observed Variables}

Maximum plant height $(\mathrm{cm})$. Observed at two weeks of age after planting, measurements were continued weekly until the maximum height was reached. Flower stalk length $(\mathrm{cm})$. Measurement before harvest, by measuring the length of the flower stalk from the ground to the tip of the highest flower. Rod diameter $(\mathrm{cm})$. By measuring the diameter of the stem with the calipers before harvest, by measuring the plant stems between the maximum height. Flower diameter $(\mathrm{cm})$. Measured using a caliper from a flower that has been in full bloom. Flower stalk weight (g). Measured by weighing the flower stalk after cutting it with an electric scale. The economic weight of fresh flowers $(\mathrm{g})$. Measured by weighing the economic value fresh flowers along $80 \mathrm{~cm}$ after harvest with an electric scale.

Pest and disease attack intensity (\%). The intensity of pest and disease attacks is measured by the formula:

$$
\text { IS }=\frac{\sum(n \times v)}{Z \times N} \times 100 \%
$$

Information :

IS = intensity of attack

$\mathrm{n}=$ Number of leaves damaged per attack category

$\mathrm{v}=$ The scale value of each attack category

$\mathrm{Z}=$ the highest category scale value of the attack category

$\mathrm{N}=$ Number of leaves observed

\section{Research Data Analysis}

Observation data were analyzed using analysis of variance if a single treatment had a significant or very significant effect followed by the smallest significant difference test at $5 \%$ level, and if there was a real or very real effect on the interaction, it was followed by multiple distance test from Duncan's level of 5\% [4]. 


\section{Results and Discussion}

The significance of the results of the effect of the application of biological agents and their interactions on all observed variables in chrysanthemum cut flowers and their interactions can be seen in Table 1.The results of the effect of Trichoderma sp and Beauveria basiana dosage treatment on the maximum average plant height $(\mathrm{cm})$, stem diameter $(\mathrm{cm}))$ ), flower stalk height $(\mathrm{cm})$, and flower stalk weight $(\mathrm{g})$ can be seen in Table 1, while the average flower diameter $(\mathrm{cm})$, fresh flower economic bobott $(\mathrm{g})$, pest attack intensity $(\%)$ and disease attack intensity (\%) can be seen in Table 2 .

Table 1. Significance of the results of the analysis of variance on the effect of the application of biological agents and their interactions on all observed variables in chrysanthemum cut flowers.

\begin{tabular}{|c|c|c|c|c|}
\hline \multirow[b]{2}{*}{ No. } & \multirow[b]{2}{*}{ Variable } & \multicolumn{3}{|c|}{ Treatment } \\
\hline & & $\begin{array}{l}\text { Trichoderma } \\
\text { sp }\end{array}$ & $\begin{array}{c}\text { Beauveria } \\
\text { basiana }\end{array}$ & $\begin{array}{c}\text { Trichoderma sp } x \\
\text { Beauveria } \\
\text { basiana }\end{array}$ \\
\hline 1 & Maximum plant height $(\mathrm{cm})$ & $* *$ & $* *$ & Mr. \\
\hline 2 & Rod diameter $(\mathrm{cm})$ & $* *$ & $*$ & Mr. \\
\hline 3 & Flower stalk height $(\mathrm{cm})$ & $* *$ & $* *$ & Mr. \\
\hline 4 & Flower stalk weight (g) & $* *$ & $*$ & Mr. \\
\hline 5 & Flower diameter $(\mathrm{cm})$ & $* *$ & $*$ & Mr. \\
\hline 6 & $\begin{array}{l}\text { Fresh flower economic weight } \\
\text { (g) }\end{array}$ & $* *$ & $*$ & Mr. \\
\hline 7 & Pest intensity $(\%)$ & $* *$ & $*$ & Mr. \\
\hline 8 & Disease attack intensity (\%) & $* *$ & $*$ & Mr. \\
\hline
\end{tabular}

Information: $*$ = significant effect, $* *=$ very significant effect, $\mathrm{tn}=$ not significant.

The results of the analysis of variance showed that, dose treatment Trichoderma sp very significant effect $(\mathrm{P}<0.01)$ on all observed variables. While the treatment of Beauveria basiana concentration had a significant effect $(\mathrm{p}<0.5)$ on all observed variables, except for the maximum plant height $(\mathrm{cm})$ and stalk height $(\mathrm{cm})$ which had a very significant effect $(\mathrm{P}<0.01)$. This shows that each treatment that was tried gave a different response to the vegetative and generative growth variables as well as the intensity of pest and disease attacks on chrysanthemums. Table 1.

Meanwhile, the interaction between dose treatments Trichoderma sp and the concentration of Beauveria basiana did not have a significant effect on all the variables observed in chrysanthemum cut flowers, this is because Trichoderma sp and Beauveria basiana at each dose and concentration had the same effect, meaning that if there was no interaction there was no co-effect between Trichoderma sp. and Beauveria basiana, and there is only the influence of each of the two factors.

The dosage treatment of Trichoderma sp resulted in the highest growth and development of plant height, stem diameter, flower stalk height, flower stalk weight, flower diameter, and the highest economic fresh flower weight. While the highest average yield in the treatment of Trichoderma sp dose in each variable is 1.5 tonnes of ha-1(Tables 2 and 3). Treatmentdosage of Trichoderma sp there was the lowest dose 0.5 ton ha-1and significantly different at each dose level tried. The results of research by the Institute for the Assessment and Development of Technology concluded that Trichoderma spp. it also has a positive effect on vegetative growth and generative development of plants and crop yields. 
Table 2. Average effect of biological agent treatment on variables of maximum plant height $(\mathrm{cm})$, stem diameter $(\mathrm{cm})$, flower stalk height $(\mathrm{cm})$ and weight of flower stalks.

\begin{tabular}{ccccc}
\hline Treatment & $\begin{array}{c}\text { Maximum plant } \\
\text { height }(\mathrm{cm})\end{array}$ & $\begin{array}{c}\text { Rod } \\
\text { diameter } \\
(\mathrm{cm})\end{array}$ & $\begin{array}{c}\text { Flower stalk } \\
\text { height }(\mathrm{cm})\end{array}$ & $\begin{array}{c}\text { Flower stalk } \\
\text { weight }(\mathrm{g})\end{array}$ \\
\hline Trichoderma spp & & & & \\
0.5 ton ha $^{-1}$ & $98.29 \mathrm{c}$ & $2.77 \mathrm{c}$ & $104.66 \mathrm{c}$ & $80.72 \mathrm{c}$ \\
1.0 ton ha $\mathrm{h}^{-1}$ & $110.82 \mathrm{~b}$ & $3.40 \mathrm{~b}$ & $112.59 \mathrm{~b}$ & $88.91 \mathrm{~b}$ \\
1.5 ton ha $^{-1}$ & $116.55 \mathrm{a}$ & $3.90 \mathrm{a}$ & $124.47 \mathrm{a}$ & $92.24 \mathrm{a}$ \\
\hline LSD 5\% & 0.17 & 0.026 & 0.23 & 0.41 \\
\hline Beauveria basiana & & & & \\
$15 \mathrm{~g} / 1$ & $106.60 \mathrm{c}$ & $3.18 \mathrm{c}$ & $112.01 \mathrm{c}$ & $84.61 \mathrm{c}$ \\
$30 \mathrm{~g} / 1$ & $108.59 \mathrm{~b}$ & $3.33 \mathrm{~b}$ & $113.76 \mathrm{~b}$ & $87.04 \mathrm{~b}$ \\
$45 \mathrm{~g} / 1$ & $110.48 \mathrm{a}$ & $3.55 \mathrm{a}$ & $115.94 \mathrm{a}$ & $90.22 \mathrm{a}$ \\
\hline LSD 5\% & 0.17 & 0.026 & 0.23 & 0.41 \\
\hline
\end{tabular}

Note: The numbers in the same column for each factor followed by the same letter are not significantly different in the LSD test at 5\% level.

Plants that were applied by Trichoderma spp. grows rapidly with fertile plant performance, fast flowering time with a lot of flowers, and a higher number of pods compared to plants that are not applied by Trichoderma spp. This result is a phenomenon in itself that shows the ability of Trichoderma spp to stimulate plant growth [5]. The fungus Trichoderma spp. It also helps plants to absorb certain nutrients, especially phosphate [6], thus allowing plants to get nutrients for their growth and development. Apart from the fungus Trichoderma sp. as a biological agent, also an activator for other microbes in the soil, a stimulator of plant growth. Trichoderma sp. are soil microbes that play a role in breaking down soil organic matter.

Table 3. Average effect of biological agent treatment on the variable flower diameter $(\mathrm{cm})$, economic weight of fresh flowers (g), intensity of pest and disease attacks (\%)

\begin{tabular}{|c|c|c|c|c|}
\hline Treatment & $\begin{array}{c}\text { Flower } \\
\text { diameter } \\
(\mathrm{cm})\end{array}$ & $\begin{array}{c}\text { Economic } \\
\text { flower fresh } \\
\text { weight }(\mathrm{g})\end{array}$ & $\begin{array}{c}\text { Pest } \\
\text { intensity } \\
(\%)\end{array}$ & $\begin{array}{c}\text { Disease attack } \\
\text { intensity }(\%)\end{array}$ \\
\hline \multicolumn{5}{|c|}{ Trichoderma sp } \\
\hline 0.5 ton $\mathrm{ha}^{-1}$ & $8.68 \mathrm{c}$ & $67.83 \mathrm{c}$ & $35.02 \mathrm{a}$ & $49.22 \mathrm{a}$ \\
\hline 1.0 ton $\mathrm{ha}^{-1}$ & $10.53 \mathrm{~b}$ & $76.40 \mathrm{~b}$ & $29.17 \mathrm{~b}$ & $44.84 \mathrm{~b}$ \\
\hline 1.5 ton $\mathrm{ha}^{-1}$ & $11.71 \mathrm{a}$ & $85.97 \mathrm{a}$ & $25.19 \mathrm{c}$ & $38.86 \mathrm{c}$ \\
\hline$L S D 5 \%$ & 0.073 & 0.48 & 0.35 & 0.35 \\
\hline \multicolumn{5}{|c|}{ Beauveria basiana } \\
\hline $15 \mathrm{~g} / 1$ & $9.81 \mathrm{c}$ & $73.64 \mathrm{c}$ & $32.09 \mathrm{a}$ & $46.42 \mathrm{a}$ \\
\hline $30 \mathrm{~g} / 1$ & $10.41 \mathrm{~b}$ & $76.99 \mathrm{~b}$ & $29.33 \mathrm{~b}$ & $44.42 \mathrm{~b}$ \\
\hline $45 \mathrm{~g} / 1$ & $10.70 \mathrm{a}$ & $79.55 \mathrm{a}$ & $27.97 \mathrm{c}$ & $42.08 \mathrm{c}$ \\
\hline LSD 5\% & 0.073 & 0.48 & 0.35 & 0.35 \\
\hline
\end{tabular}

Note: The numbers in the same column for each factor followed by the same letter are not significantly different in the LSD test at $5 \%$ level.

The highest fresh weight of economic flowers was $85.97 \mathrm{~g}$ produced by the treatment of Trichoderma sp. 1.5 ton ha dose-1, and the lowest was generated at the treatment dose Trichoderma sp 0.5 ton ha- 1 amounting to $67.83 \mathrm{~g}$. Terjadi increased yield of $21.10 \%$ when compared with treatment dose Trichoderma Lowest. Economic fresh interest weight on 
treatmentdose Trichoderma 1.5 ton ha-1significant effect with other dose levels on each observed variable (Table 3 ).

The lowest intensity of pest and disease attacks is found at the dosage Trichoderma sp 1.5 ton ha- 1 for: $25.19 \%$ and $38.86 \%$, and the highest in treatmentdose Trichoderma sp 0.5 ton ha1 for: $35.02 \%$ and $49.22 \%$. There was a decrease in the intensity of pests and diseases, respectively: $28.07 \%$ and $21.04 \%$ when compared to the treatment with the highest attack. The results of the research giving Tricodarma sp to seedling height can cause plants to be more resistant to wilt disease because more trichoderma colonies have a faster ability to grow meselium so that there is a change in the use of secondary water metabolites which should be used by pathogens for their mycelium growth, this antagonistic nature makes pathogens that cause fusarium wilt disease are not able to compete so that their metabolic activity is disrupted which causes the attack of these pathogens to be inhibited [8].

Beauveria basiana concentration treatment $45 \mathrm{~g} / 1$ at each level of treatment tested had a significant effect on all observed variables. Weight fresh flowers are the highest economical $79.55 \mathrm{~g}$ produced by treatment of Beauveria basiana concentration $45 \mathrm{~g} / 1$, and the lowest was produced in the treatment the concentration of Beauveria basiana $15 \mathrm{~g} / 1$ amounting to $73.64 \mathrm{~g}$. TThere was an increase in yield of $7.43 \%$ when compared to the lowest concentration of Beauveria basiana. The lowest intensity of pest and disease attacks occurred in the concentration of Beauveria basiana45 g / 1 of $27.97 \%$ and $42.08 \%$, the highest pests and diseases were found in the Beauveria basiana treatment with a concentration of $15 \mathrm{~g} / 1$, namely $32.09 \%$ and $46.42 \%$. There was a decrease in disease attack on the use of Beauveria basiana by each; $12.84 \%$ and $9.35 \%$. The role of endophytic fungi in agriculture can increase plant resistance against pests and plant diseases, as well as the ability to stimulate germination and plant growth [9].It is also stated that the higher the concentration is applied, the higher the conidia density of the fungus, so that the possibility of conidia sticking to the insect's body will increase, which results in faster penetration of the insect's body and damage to the insect's body tissue. Beauvericin which can cause disturbances in the function of hemophilia and the nucleus of host insects, Beauveria bassiana infects host insects through physical contact, namely by attaching conidia to the integument, then growing their mycelias in the host's body which causes their immunity to decrease, in 3-5 days the insect will die. which is characterized by conidia growth on the integument [10].

\section{Conclusion}

- The interaction between the treatments of Trichoderma sp and Beauveria basiana had no significant effect on all observed variables.

- Trichoderma sp treatment had a very significant effect $(\mathrm{P}<0.01)$ on all observed variables. The highest economic fresh interest weight is $85.97 \mathrm{~g}$ produced by the treatment dose Trichoderma sp 1.5 ton ha-1, terjadi increased $21.10 \%$ yield when compared with treatment dose Trichoderma sp Lowest.

- The treatment of Beauveria basiana had significant $(\mathrm{P}<0.05)$ to very significant $(\mathrm{P}<0.01)$ effects on all observed variables. Weight fresh flowers are the highest economical $79.55 \mathrm{~g}$ produced by treatment of Beauveria basiana concentration $45 \mathrm{~g} / 1$, There was an increase in yield of $7.43 \%$ when compared to the lowest treatment.

- The lowest intensity of pest and disease attacks was found at the Trichoderma dose of 1.5 tonnes of ha- 1 and concentration Beauveria basiana $45 \mathrm{~g} / 1$ of $25.19 \%$ and $42.08 \%$. 


\section{Acknowledgement}

Thank you very much to Warmadewa University Research Institute for funding applied product research in 2020. As well as friends and students who have helped carry out this research.

\section{Reference}

[1]. H. R. Rukmana, "Chrysanthemum.” Yogyakarta: Kanisius, 1997.

[2]. I. G. M. Arjana, P. S. Yohanes, and I. N. Suaria, "Increasing the Production and Quality of Chrysanthemum Flowers through the Technological Package for Plant material cuttings." Denpasar: Competitive Research Grant, Faculty of Agriculture, Warmadewa University, 2014.

[3]. Darti, "Plants and Cultivation of Ornamental Plants." Jakarta: PD. Mahkota, 1992.

[4]. K. A. Hanafiah, "Experimental Design, Theory \& Application." Jakarta: PT. Raja Grafindo, 2001

[5]. I. M. S. Antara, Rosmini, and P. Johanis, "Effect Of Various Doses Of The Trichoderma Spp To Control Fusarium Oxysporum Wilt In Tomato Plants." $J$. Agrotechbis, vol 3, no 5, pp. 622-629, 2015.

[6]. E. Rokhminarsi, D. S. Utami, and Begananda, "Penerapan Pupuk Mikotricho (Mikoriza-Trichoderma) dan Pupuk Sintetik Pada Budidaya Cabai Merah", J Hort Indonesia, vol. 10, no. 3, pp. 154-160, Dec. 2019.

[7]. F. M. Bayfurqon, N. W. Saputro, and M. B. R Khamid, "Pengaruh Pupuk Kandang Sapi dan Inokulan Mikroba Trichoderma sp. terhadap Pertumbuhan dan Hasil Tanaman Caisim (Brassica juncea (L.) Czern).”, J. Pertanian Presisi, vol,. 1, no. 1, 2017.

[8]. B. Bukhari and N. Safridar, "Efisiensi Penggunaan Trichoderma Sp Untuk Mengendalikan Penyakit Layu Fusarium (Fusarium Oxysporium) Dan Pertumbuhan Bibit Tanaman Pisang”, J. Ilm. Pertan., vol. 14, no. 2, pp. 14-28, Mar. 2018.

[9]. M. Saragih, T. Trizelia, N. Nurbailis, and Y. Yusniwati, "Uji Potensi Cendawan Endofit Beauveria bassiana terhadap Perkecambahan dan Pertumbuhan Bibit Tanaman Cabai Merah (Capsicum annuum L.)", Unricsagr, vol. 1, pp. 151-159, Jan. 2019.

[10]. D. Y. Intarti, I. Kurniasari, and A Sudjianto, "Efektivitas Agen Hayati Beauveria bassiana dalam Menekan Hama Thrips sp. pada Tanaman Cabai Rawit (Capcisum frutescens L.)." Agrovigor: Jurnal Agroekoteknologi, vol. 13, no. 1, pp. 10-15, 2020 . 